\title{
Civil Law in Forced Unions. The Austrian Civil Code and its Significance for the Development of Civil Law in Central Europe ${ }^{1}$
}

\begin{abstract}
The current Austrian Civil Code goes back to 1811, after more than 200 years it still is in force in Austria - though with many amendments. Its origin and development is connected to the political history of the Austrian Empire, later the Dual Monarchy and its successor states in the 20th century. The paper analyses the significance of the Austrian Civil Code on the development of civil law in Central Europe on the verge of the collapse of the old empires and the emergence of the new political systems. Especially the question of the influence of the Austrian Civil Code on Polish law and inversely the influence of Polish lawyers on the development of the Austrian Civil Code is addressed. Due to the character of the inclusion of the Polish parts into the Austrian Empire in the 18th century the paper raises the question of the role of civil law in forced unions.
\end{abstract}

Keywords: Austrian Civil Code, Galicia, civil law, pactum advitalitium, Ernest Till

Słowa kluczowe: austriacki kodeks cywilny, Galicja, prawo cywilne, pactum advitalitium, Ernest Till

\section{Introduction}

The 18th century was a very turbulent period for the Polish state, ending with the division of the territory of the Polish-Lithuanian Commonwealth among its neighbors, the Kingdom of Prussia, the Russian Empire and Habsburg Austria. The Polish state ceased to exist for 123 years until its resurrection after World War I. Its death occurred gradually - the territory being split three times in 1772, 1793 and 1795 respectively. ${ }^{2}$ This paper focuses only on the Austrian part of the former Polish territory, which in the Austrian

${ }^{1}$ This article is a slightly revised version of my lecture at the Jagiellonian University (20. 09. 2019). I would like to thank Mr Ramon Pils, DipTrans for his help with the English version of the text. This article outlines some issues that will be discussed in detail in my habilitation thesis.

2 Bömelburg, Gestrich, Schnabel-Schüle, „Die Teilungen”, 9-35. 
period was called Kingdom of Galicia and Lodomeria. ${ }^{3}$ In the 18th century, the Habsburg monarchy was a monarchische Union von Ständestaaten, ${ }^{4}$ a union of individual states controlled by the estates of the realm and held together by the same monarch - hence the term "union" in the title of this paper. As the term "union" is today primarily used for an arrangement that is approved by the parties involved, in the case of Galicia a further distinction should be made. Galicia becoming a part of the Habsburg Empire was hardly an approved union in this sense. Therefore, the term "forced union" is used. Still, de lege the first partition was sanctioned by a treaty and ratified by the Polish parliament; after the third partition the king abdicated..$^{5}$ These legal acts were meant to uphold the appearance of a legitimate transformation, but still the parliament acted under pressure. ${ }^{6}$

The aim of the paper is to give an overview of the different aspects of civil law in a forced union, illustrated primarily with the case of Galicia. It examines the role of civil law in the incorporation of Galicia into the Austrian Empire on the one hand, and the role of Polish law and Polish legal scholars in the development of Austrian civil law on the other. The paper concludes with an outline of the significance of Austrian civil law in the interwar period.

The question of language and mutual understanding, in particular, is of great importance in the field of law. On the one hand the acceptance and application of the law requires the comprehension of the legal text by the people who are bound by it. On the other hand, courts and administrative bodies are able to work more efficiently if they have a common language with the populace who is the addressee of the norms. The problem of a common language was evidently one of the main issues in the Austrian Empire as well as in the Austro-Hungarian Dual state. The article gives some insight into the different layers of this problem with regard to civil law and Galicia.

Despite these difficulties regarding the common language, this contribution seeks to illustrate the unifying power of civil law in a union of states.

\section{Civil Law and the Kingdom of Galicia and Lodomeria}

The question of the role of civil law in state unions and, in this specific example, in the forced union with Galicia leads us to the implementation of Austrian civil law in the new territories. At the time of the first partition, Austria was in the middle of developing its first civil code, hence at first, Polish law remained in force in Galicia. The codification process took several decades and a few legal codes were temporarily applicable until finally in 1811, the Austrian civil code was enacted. But earlier in the 1770s, a partial unification of civil law in the Habsburg territories had taken place: In 1783 a marriage law was passed, in 1786 inheritance law followed, and in the same year the so called

3 From 1803 to 1809 West Galicia was part of the Kingdom of Galicia and Lodomeria. Druschel, "Die Einführung”, 291-320, 308.

4 Brunner, Land und Herrschaft, 447; Schneider, "Zwischen", 31-49.

5 Druschel, "Die Einführung", 296.

${ }^{6}$ Grodziski, Historia ustroju, 26; Bieniek, Rozbiory Polski, 32-37. 
Josephinian Civil Code was enacted. ${ }^{7}$ The Josephinian Civil Code regulated only parts of civil law and was meant to later become the first part of the Austrian Civil Code, but due to the death of Emperor Joseph II. in 1790, the codification process stagnated. Hence there was a mixture of Polish and Austrian civil law applied in Galicia between 1787 and 1798.

Unlike in the Kingdom of Galicia and Lodomeria, the Austrian legislator replaced the old Polish law in West Galicia quite quickly. This fact is not surprising, as in 1772 there had been no Austrian civil law codification; the work on the unification of the civil law had since then made great progress. At the time of the third partition, in October 1795, the Josephinian Civil Code was still in force in the Habsburg territories, however it did not cover the entire private law, as the codification process was still not finished. The monarch did not expand the Josephinian Civil Code to the West Galician territory; rather he waited with the implementation of Austrian civil law until the revised version of the code was reasonably well advanced. ${ }^{8}$ The West Galician Code - a predecessor of the Austrian Civil Code - was introduced in West Galicia in 1797 and subsequently in the entire Galicia and Bukovina. ${ }^{9}$ In February 1797, the West Galician Code was published in the law gazette (called the Justizgesetzsammlung). ${ }^{10}$ The West Galician Code was introduced in the Kingdom of Galicia and Lodomeria even before it came into effect in West Galicia. ${ }^{11}$

The West Galician Code was - as Wilhelm Brauneder and Christian Neschwara have pointed out - the first complete modern civil code. ${ }^{12}$ It came into force in January 1798. Contemporary literature as well as the commentaries on the Austrian Civil Code stressed the necessity to implement the new code in West Galicia as quickly as possible. ${ }^{13}$ The reason for this haste was the need to strengthen the Habsburg rule in this new territory and to provide it with a modern legal code. From a practical point of view, the new code made the administration of West Galicia easier, as it was based on familiar law, unlike Polish law. The code was published not only in the official German version, but immediately also in Polish and Latin translations. ${ }^{14}$

Both territories needed a unified modern law to develop legal stability. Although the goal was to implement a unified law in the entire Habsburg Empire, Galicia especially needed to be settled as it had only recently been acquired and also due to the subliminal reservations of the Polish inhabitants against the three powers. Additionally, the implementation of the new code in one part of the Empire provided the ruler with an

\footnotetext{
7 Patent v. 1. 10. 1786, Justizgesetzsammlung Nr 591.

${ }^{8}$ Brauneder, "Europas erste Privatrechtskodifikation", 308. On the last minute changes in the text of the West Galician Code cf. Pfaff, ,Zur Entstehungsgeschichte”, 399ff., 411ff., 423ff., 435ff.

9 Brauneder, "Europas erste Privatrechtskodifikation", 309.

10 Patent v. 13. 2. 1797, Justizgesetzsammlung Nr 337.

11 Patent v. 8. 9. 1797, Justizgesetzsammlung Nr 373.

12 Brauneder, Österreichs, 42; Brauneder, "Europas erste Privatrechtskodifikation", 305; Neschwara, „Westgalizisches Gesetzbuch”, $1308 \mathrm{f}$.

13 Zeiller, Commentar, 10.

14 Neschwara; Karl Anton Martini, 3-17, p. 15. For an overview of the different editions of this civil code cf. W. Brauneder, "Europas erste Privatrechtskodifikation", 306-8.
} 
opportunity to test the new rules in practice before implementing them across the entire Empire. ${ }^{15}$

The implementation of a modern, general law that abolished local laws and customs in the newly acquired territory took place not only in the domain of civil law, but also in criminal law and civil procedure. ${ }^{16}$ The overall goal was to strengthen the central power of the monarch and to diminish the influence of peripheral and local wielders of power. Hence these legal codes strengthened the union of states held together by the monarch and therefore had an unifying function.

Although the West Galician Code was enacted especially for this territory, it did not contain any provisions based on Polish law. In 1796 the latest draft of the civil code was distributed to different legal experts; among others three courts in formerly Polish territory were called upon to give their opinions on the draft. ${ }^{17}$ Some of their remarks were considered in the debates on the final Austrian civil code - as will be shown later.

An important aspect of lawmaking and application of the law is - as already mentioned - the question of language. In the case of Galicia, the transition to the German language as obligatory in courts and administration was a challenge, a process that was approached gradually. Originally legal acts of the sovereign were published in Latin and in Polish, ${ }^{18}$ and courts were allowed to hold on to Latin for the time being. ${ }^{19}$ The attempt to introduce German as the obligatory language in courts failed, but the German language was used more frequently between public authorities. ${ }^{20}$ All in all the use of Latin was decreasing, so that legal acts concerning only Galicia were published in German and Polish from 1782 onward. ${ }^{21}$

\section{The Influence of Polish Law on the Austrian Civil Code}

Although different commissions were set up to prepare expert opinions on the drafts of the Austrian civil code, at first none of them focused particularly on local law. ${ }^{22}$ Nevertheless, some members of these commissions had knowledge of the local customs and laws of Galicia and Lodomeria. Still there were hardly any suggestions concerning the inclusion of local law that was in force in Galicia into the Austrian codification. This fact is not surprising if we look at the objective of the codification: to introduce a unified,

15 Neschwara, Karl Anton Martini, 11. Some authors suggested that the code was primarily implemented to be trialed - against this assumption cf. Brauneder, "Europas erste Privatrechtskodifikation", 309-12.

16 Brauneder, "Europas erste Privatrechtskodifikation", 308. The difficulties in the adaptation of the civil procedure is described by Grodziski, "Justizreformen", 123-32.

17 Till, Obrady trybunatu, 3; Druschel, "Die Einführung", 311-5.

${ }_{18} \mathrm{Cf}$. Edicta et mandata universalia regnis Galiciae et Lodomeriae a die 11. Septembr. 1772 initae possessionis promulgata.

${ }^{19}$ Latin was the official language used in the courts of the Polish-Lithuanian Commonwealth. Cf. Druschel, "Kommunikation", 63-80, 68.

20 Druschel, „Kommunikation”, 71-73.

${ }^{21} \mathrm{Cf}$. Continuatio edictorum et mandatorum universalium in regnis Galiciae et Lodomeriae a Die 1. Januarii ad ultimam Decembris 1782 emanatorum.

22 Brauneder, Österreichs, 80. 
general civil law based on the principles of natural law. ${ }^{23}$ Local laws, however, lacked the universal scope required and hence did not fit into the codification. There was one prominent exception - a local custom that found its way into the ABGB - the pactum advitalitium, a legal institute familiar from the old Polish law. ${ }^{24}$

The pactum advitalitium was a provision that benefitted a married person in case their spouse died before them. This legal institution gave the widowed spouse the right to use and derive profit - the usufruct - from the estate of their deceased partner for their lifetime or until they remarried. Often it was used to provide financial security for the widow. The old Polish "legal system did not provide for commune marital property [and] there was no statutory spousal succession." ${ }^{25}$ As already mentioned, the pactum advitalitium was not implemented in the West Galician Code. As the West Galician Code was used in the further debates on the Austrian civil code, the pactum advitalitium was missing there as well, a fact criticized in one of the Galician expert opinions. ${ }^{26}$ Only in 1807 found the pactum advitalitium its way into the draft: In November 1807 Carl v. Pratobevera, a member of the commission that developed the final draft of the Austrian Civil Code, brought up the pactum advitalitium as a legal institute common in Galicia. ${ }^{27}$ Due to the incorporation of the slightly modified pactum advitalitium into the ABGB at such a late point, many questions concerning its application were not addressed by the code. In the following decades the pactum advitalitium was discussed by legal scholars; especially its legal nature was controversial. ${ }^{28}$ In practice this legal instrument was - according to contemporary legal scholars - of no importance. ${ }^{29}$ The pactum advitalitium did not gain recognition in the Austrian Empire, respectively Cisleithania; nevertheless it was occasionally mentioned by the Austrian Supreme Court of Justice. ${ }^{30}$ It seemed to be used still in Galicia as a newspaper article from 1837 indicates, which mentions a pactum advitalitium in favor of Countess Maria Potocka brought up in a dispute before the Galician commercial court. ${ }^{31}$ Even after the breakup of the Dual Monarchy, we find some evidence of the existence of the pactum advitalitium, at least in popular perception. The commentary on the Austrian Civil Code from $1936^{32}$ mentions a decision of the Supreme Court from 1921. ${ }^{33}$ Even in the 1930s, the term Advitalität was popular enough to be explained as a foreign word in the "Neue Wiener Friseur Zeitung", a journal addressed to Vienna's hairdressers. ${ }^{34}$ Eventually the pactum advitalitium stayed in the Austrian civil law until 2009; there were sporadic mentions of it in court decisions up to the $1940 \mathrm{~s}^{35}$, and even now the term occurs in civil law textbooks. ${ }^{36}$

\footnotetext{
23 Brauneder, "Europas erste Privatrechtskodifikation", 315.

${ }^{24}$ Cf. Bokwa, Jarosz, "Czy na pewno”, 109-124.

25 Ibid., 110.

26 Till, Obrady, $11 \mathrm{f}$.

27 Ofner, Der Ur-Entwurf, 432f.

${ }^{28}$ Cf. Lenhoff, " $\$ \$ 1255-1258 ”, 830-832$ with further references.

29 Zobkow, „Das österreichische”, 747.

30 Bokwa, Jarosz, "Czy na pewno", 116.

31 Dodatek do „Gazety Lwowskiej”, Nr 59, 20. 5. 1837, 930.

32 Schey, Das Allgemeine, 695.

33 Entscheidung des Obersten Gerichtshofes v. 12. 1. 1921, Ob 11 9/21, SZ III 3.

34 Neue Wiener Friseur-Zeitung, Nr 21, 1. 11. 1931, 18.

35 Entscheidung des Obersten Gerichtshofes v. 8. 12. 1948, 2 Ob 364/48.

36 Welser, Kletečka, Grundriss des bürgerlichen Rechts I, Wien 2018, 536.
} 
In 2009 the provisions on the pactum advitalitium were abrogated due to their lack of applicability. ${ }^{37}$

Although the pactum advitalitium was not commonly used in practice, it gives us an example of how general and unified law codes can also incorporate local customs.

\section{A Side Note: The Hungarian Kingdom and the Austrian Civil Code ${ }^{38}$}

We find another case of a forced union in relation to the civil law of the Habsburg monarchy in the neo-absolutistic era between 1852 and 1860. In 1849, the Austrian emperor passed a new centralistic constitution for the entire Habsburg Empire and consequently revoked the Hungarian constitution of 1848 following the uprisings in 1848 and $1849 .{ }^{39}$ This step led to the dethronement of the Habsburg monarch by the Hungarians. The Hungarian war of independence failed, and in the summer of 1849, the Hungarian army was defeated. A centralistic and since 1852 absolutistic period followed. At this time, the Hungarian private law was not yet codified. To strengthen the hold on the Hungarian territories as well as to unify and centralize the legal order in the Austrian Empire, in 1852, the monarch implemented the Austrian Civil Code in Hungary. ${ }^{40}$ It came into force in January 1853. With the end of the absolutistic era, the Austrian Civil Code was abrogated in Hungary in 1861 - however it remained an academic discipline at the Hungarian universities as well as a source of law in specific areas. ${ }^{41}$

\section{Jurisprudence in Galicia: "Polish" Legal Scholars and the Development of the Austrian Civil Code}

Important circles of jurisprudence developed in 19th century Galicia, starting with the law school in Lviv. At first scholars who had studied in Vienna were appointed as law professors. For example, Joseph von Winiwarter and Ignaz Grassl - both notable scholars - each taught Austrian civil law in Lviv for 20 years. ${ }^{42}$ Afterwards they were appointed professors at the Viennese law faculty, hence their employment in Lviv served as a starting point for their academic careers. Even before the University of Lviv was reestablished, ${ }^{43}$ the first legal journal ("Annales Jurisprudentiae pro regnis Galiciae et

37 Initiativantrag 673/A BlgNR 24. GP 29; BGB1 I 2009/75.

38 Neschwara, „Das ABGB”, 33-133; Busch, Besenböck, „Von Mailand”, 535-597.

39 Arbeitsgemeinschaft (eds.), Rechts- und Verfassungsgeschichte, 197, 207.

40 Neschwara, ,Das ABGB”, 54.

${ }^{41}$ Ibid., 91-108, 126.

42 Redzik, Prawo prywatne, 49.

43 In 1805 the University of Lviv was transferred to and merged with the University of Cracow; in 1817 the University of Lviv was reestablished. Cf. Redzik, Prawo prywatne, $3 \mathrm{f}$. 
Lodomeriae") documented the work of the legal scholars living and working in the city. Until the implementation of the Austrian Civil Code in 1811, the journal was published in Latin, later - from 1812 on - it switched to German. ${ }^{44}$ At first, Polish legal scholars had almost no influence on the civil law doctrine at the University of Lviv; due to political reasons they usually did not become professors. ${ }^{45}$

After the revolution of 1848 a new era began - not only from the constitutional point of view, but regarding the universities and legal scholarship as well. ${ }^{46}$ The minister of education Leo Thun-Hohenstein reformed the universities and implemented the Humboldtian model of higher education at the Austrian universities. The new provisions regarding legal studies concentrated on the historical background of the legal order and banished natural law, which was held responsible for the revolution of 1848, from the curriculum. ${ }^{47}$ Significant for this period in civil law jurisprudence was especially the Historical School of Jurisprudence and its practical realization in pandectistics. This development led in the first place to an increased study of the Austrian Civil Code from a fresh point of view. Secondly - as a result - many academic texts on the Austrian Civil Code adopted the system of pandects, the authors being - in terms of the language in which they wrote - not only Austrian scholars, but Polish ones as well. This fact leads us back to the question of the influence that Polish lawyers had on civil law doctrine and jurisprudence. Whereas in the beginning the opportunities for Polish legal scholars in academia were limited, gradually the number of academic studies, translations, commentaries written by Polish legal scholars increased. One of the reasons for this development was the change of the official language policy in the educational system. The intensified study of the Austrian civil law and the possibility to do this in their native language strengthened the relationship between the Polish legal scholars and the Austrian Civil Code.

From the 1860s onward, the University of Cracow was allowed to teach law in the Polish language, ten years later the University of Lviv followed. ${ }^{48}$ Likewise, from 1870 onward, the law gazette was published not only in German but also in the other languages of the monarchy. These factors fueled a growing interest in legal questions in the Austrian Dual Monarchy, and the discussions among scholars about civil law and its development were reinforced by the codification movements all over Europe. For Austrian legal scholarship, especially the development of the German civil code and the Swiss private law was of great importance.

Going back to the Galician legal scholars, we observe an increasing number of Polish legal scholars from the 1860s onward. ${ }^{49}$ One of the most important legal scholars from Galicia was Ernest Till, ${ }^{50}$ a scholar who continues to be well known in Poland and is still mentioned in Austrian text books on legal history as well..$^{51}$ Looking back at his academic life we can see the connection between the Galician legal doctrine of civil law and its

\footnotetext{
44 Redzik, Prawo prywatne, 48f with further references.

45 Sójka-Zielińska, Wielkie kodyfikacje, $160 \mathrm{f}$.

46 Ogris, "Die Universitätsreform", 333-344; Lentze, Die Universitätsreform, passim.

47 Olechowski, "Jurisprudenz", 401-416, 402f.

48 Staudigl-Ciechowicz, "Zwischen”, 223-238, $224 \mathrm{f}$.

49 Redzik, Prawo prywatne, 50.

50 Longchamps de Berier, Ernest Till, 1926.

51 Arbeitsgemeinschaft (eds.), Rechts- und Verfassungsgeschichte, 241.
} 
impact on Austrian legal scholarship as well as on the Polish legal order after the resurrection of the Polish state. Ernest Till studied at the Universities of Lviv and Cracow and obtained his venia legendi at the University of Cracow in 1877. Subsequently he worked as a lawyer in Lviv and taught civil law at the University, from 1905 as a full professor. Ernest Till's work was especially significant for generations of law students as he wrote the first text book on the Austrian Civil Code in the Polish language. Its first part was published in 1884, the sixth and last part in $1904 .{ }^{52}$ An inspiration for Till's textbook was a book published in 1856 by Joseph Unger that had introduced the system of the pandects into the Austrian textbooks on civil law. ${ }^{53}$ Till's textbook was not only a valuable tool for law students but as one of the few works that presented the whole Austrian Civil Code in the Polish language, it was crucial for the development of a Polish legal terminology on Austrian civil law. ${ }^{54}$ Till's work did not just focus on commenting and describing the civil law in Polish, he also published several papers on different aspects of civil law in German. ${ }^{55}$ Hence it is not surprising that he took an interest in reforming the Austrian Civil Code and published his findings in both Polish and German. ${ }^{56}$ For almost 30 years Till practiced as a lawyer, hence his comments on the reform of the Austrian Code included his suggestions as a practitioner as well. The fact that in February 1908 he was invited to present his views on the reform to the Wiener Juristische Gesellschaft - an association of leading legal scholars and practitioners based in Vienna - shows that he was not only known and respected in the Polish speaking legal community but in the German speaking one as well. ${ }^{57}$ Several other legal scholars from Galicia also got involved in the debates on the need of a reform of the Austrian Civil Code. Among the leading scholars was Stanisław Madeyski-Poray, a former professor of civil law at the University of Cracow, who pursued a political career, was a member of the Austrian House of Lords and a member of the first commission tasked with drafting a revision of the Austrian Civil Code, which was established in 1904. ${ }^{58}$ Although this specific commission failed to achieve this goal, the presence of Madeyski provides another example of the growing recognition of Galician legal scholars in Cisleithania. Finally, Fryderyk Zoll (jun.) needs to be mentioned. Zoll obtained his venia legendi at the University of Vienna and was appointed professor at the University of Cracow a few years later. Zoll was involved in the draft of the Austrian international private law. ${ }^{59}$ Many of these scholars played an important role in the formation of Polish civil law after the collapse of the Dual Monarchy, which leads to the question of the lasting effects of private law as unifying factor even beyond national borders.

52 Till, Prawo prywatne, passim.

53 Unger, System, 1856.

54 Longchamps de Berier, Ernest Till, 12.

55 For a bibliography of his works cf. Redzik, Prawo prywatne, LIVff.

${ }^{56}$ E.g. Till, "Czy rewizja", 601-614; Till, "Revision oder", 41-45.

57 A. E., "Wiener", 89f.

58 Dölemeyer, "Die drei", 1782-1799, 1797.

59 Mączyński (ed.), Fryderyk, passim. 


\section{The Consequences of the Common Civil Law in the $20^{\text {th }}$ Century}

After the disintegration of Austria-Hungary, the Austrian Civil Code remained effective not only in Austria, but (during the interwar period) also in some other successor states and in Liechtenstein. As a result, the "Austrian Civil Law Realm" lasted longer than the House of Habsburg's rule in Central Europe.$^{60}$ In the interwar period, the Code as amended by the important partial amendments from 1914-1916 was also applied in the previously Austrian parts of Poland, ${ }^{61}$ in the Czech part of Czechoslovakia, in some parts of the Kingdom of Serbs, Croats and Slovenes (Dalmatia and Slovenia) and in Bukovina, which now belonged to Romania. Only with the implementation of socialist private law codes after the World War II did the ABGB lose its significance as a supranational bracket on private law.

However, already in the interwar period the civil law realm was slowly breaking apart. In Poland a special commission was established whose task it was to prepare drafts on different fields of law - among others also on civil law. ${ }^{62}$ Among the members of the Codification Commission were several legal scholars and practitioners from Galicia. ${ }^{63}$ The commission was partly successful, however they were not able to finish their work as far as the entire civil law was concerned, but a Code of Obligations was successfully implemented.$^{64}$ Even though the Austrian Civil Code was not used as a foundation for the new codification, it still influenced the process to some degree - on a personal level, as some members were very familiar with the Austrian Code and its legal tradition, ${ }^{65}$ and on the other hand as the Austrian Civil Code was included in the comparative analysis of different legal solutions prepared by the Commission. ${ }^{66}$ In Czechoslovakia and Yugoslavia unification processes in civil law were initiated as well, but unlike in Poland their drafts were based upon the Austrian Civil Code and in both cases they never came into effect. ${ }^{67}$

In Austria the Civil Code of 1811 remained in force after World War I. ${ }^{68}$ Although certain parts of the Austrian civil law - especially marriage and divorce law - were in need of revision, plans to modernize this field of law were not successful. ${ }^{69}$ It was too emotionally and ideologically charged, and the political situation was not in favor of

60 Slapnicka, Österreichs Recht, 11-14, 71-77.

61 Dziadzio, “Das ABGB in Polen”, 205-226, 205f; Malec, „Das ABGB”, 235-253.

62 Górnicki, Prawo cywilne, passim.

63 Grodziski, "Komisja Kodyfikacyjna", 47-81. He names among others: Ernest Till, Fryderyk Zoll, Maurycy Allerhand, Aleksander Doliński, Tadeusz Dziurzyński, Franciszek Ksawery Fierich, Stanisław Gołąb, Antoni Górski, Roman Longchamps de Berier.

${ }^{64}$ Kodeks zobowązań, Rozporządzenie Prezydenta Rzeczypospolitej z dn. 27.10.1933 r. Dziennik Ustaw $1933 \mathrm{Nr}$ 82, poz. 598.

65 Malec, „Das ABGB”, 244-246.

66 Dziadzio, „Das ABGB in Polen”, 219.

67 Drakić, “Jugoslawien”, 195-225; Salák, „Tschechoslowakei, 91-148.

68 For an overview of the Austrian civil law in the interwar period see Staudigl-Ciechowicz, „Österreich, 39-69.

69 Harmat, Ehe auf Widerruf?, passim. 
such changes. The common legal framework was shrinking, but legal practitioners and schools of the post-Cisleithanian area still kept up with the developments in its former realm. $^{70}$

\section{Conclusions}

The example of the West Galician Code shows the attempt to embed the Austrian civil law and hence the Austrian legal order in the newly acquired territory. In this case, the civil law to some extent served the purpose of strengthening the forced union. A similar conclusion can be drawn in the case of Hungary and the implementation there of the Austrian Civil Code in 1852. To enforce the Austrian legal order and to install civil servants loyal to the emperor in the insurgent regions, in both cases a unified law had to be implemented with which the civil servants were already familiar. While in Hungary the Austrian Civil Code never gained a prominent role, Galician scholars developed not only their own civil law doctrine but were actively partaking in the debates on the civil code. Especially the influence of these scholars on the Austrian legal order should be remembered today and deserves to be researched in greater detail. An important factor that strengthened the development of a Polish speaking jurisprudence in the Austrian Empire was the continued usage of the Polish language even after the partitions. Although the German versions of official legal documents were in dubito the legally binding ones, the continued existence of a Polish language in the legal domain still facilitated the formation of a modern Polish legal terminology.

\section{Bibliography}

A.E., “Wiener Juristische Gesellschaft”, Juristische Blätter 37 (1908): 89-90.

Arbeitsgemeinschaft Österreichische Rechtsgeschichte (eds.). Rechts- und Verfassungsgeschichte 5. Auflage, Wien: Facultas, 2018.

Bieniek, Andrzej. Rozbiory Polski w świetle prawa międzynarodowego [The partitions of Poland in the light of international law]. Warszawa: [s.n.], 1934.

Bokwa, Krzysztof i Jarosz, Iwo. "Czy na pewno martwa instytucja? Staropolskie i austriackie pactum advitalitium w perspektywie współczesnej" [Definitly dead law? Old Polish and Austrian pactum advitalitium in the contemporary perspective]. Studenckie Prace Prawnicze, Administratywistyczne i Ekonomiczne [Student Legal, Administrative and Economic Works] 25 (2018): 109-124.

Bömelburg, Hans-J., Gestrich, Andreas, Schnabel-Schüle, Helga. "Die Teilungen Polen-Litauens als Zäsur einer europäischen Strukturgeschichte". In Die Teilungen Polen-Litauens. Inklusions- und Exklusionsmechanismen - Traditionsbildung - Vergleichsebenen, eds. Hans-J. Bömelburg, Andreas Gestrich and Helga Schnabel-Schüle, 9-35. Osnabrück: Fibre Verlag, 2013.

\footnotetext{
${ }^{70}$ The recently started habilitation project of the author seeks to deepen this topic.
} 
Brauneder, Wilhelm. "Europas erste Privatrechtskodifikation: Das Galizische Bürgerliche Gesetzbuch". In Naturrecht und Privatrechtskodifikation. Tagungsband des Martini-Colloquiums 1998, eds. Heinz Barta, Rudolf Palme and W. Ingenhaeff, 303-320. Wien: Manz, 1999.

Brauneder, Wilhelm. Österreichs Allgemeines Bürgerliches Gesetzbuch (ABGB). Eine europäische Privatrechtskodifikation I: Entstehung und Entwicklung des ABGB bis 1900. Berlin: Duncker \& Humblot, 2014.

Brunner, Otto, Land und Herrschaft. Grundfragen der territorialen Verfassungsgeschichte Österreichs im Mittelalter. 5. Auflage. Wien-Wiesbaden: R.M. Rohrer, 1965.

Busch, Jürgen and Besenböck, Alexander. "Von Mailand bis Czernowitz. Die Einführung des österreichischen ABGB, Gesamtstaatsidee und nationaler Partikularismus". In Europa und seine Regionen. 2000 Jahre Rechtsgeschichte, eds. Andreas Bauer, Karl H. Welker, 535-597. Köln: Böhlau, 2007.

Dölemeyer, Barbara. "Die drei Teilnovellen zum ABGB (1914-1916) ". In Handbuch der Quellen und Literatur der neueren europäischen Privatrechtsgeschichte III/2, ed. Helmut Coing, 1782-99. München: C.H.Beck Verlag, 1982.

Drakić, Gordana. "Jugoslawien: Codification of Civil Law in the Yugoslav State between the two World Wars". In "Nichtgeborene Kinder des Liberalismus"? Zivilgesetzgebung im Mitteleuropa der Zwischenkriegszeit, eds. Martin Löhnig, Stephan Wagner, 195-225. Tübingen: Mohr Siebeck, 2018.

Druschel, Daniela. "Die Einführung des habsburgischen Rechts in Galizien. Herrschaftswechsel als Reformmotor für die Straf- und Zivilrechtskodifikation in der Habsburgermonarchie?". In Die Teilungen Polen-Litauens. Inklusions- und Exklusionsmechanismen - Traditionsbildung - Vergleichsebenen, eds. Hans-J. Bömelburg, Andreas Gestrich, Helga Schnabel-Schüle, 291-320. Osnabrück: Fibre Verlag, 2013.

Druschel, Daniela. "Kommunikation zwischen Zentrale und Peripherie. Wien und Galizien 1772-1848". In Kommunikation über Grenzen. Polen als Schauplatz transnationaler Akteure von den Teilungen bis heute, eds. Lisa Bicknell, Benjamin Conrad, Hans-Christian Petersen, 63-80. Berlin: 2013 (= Mainer Beiträge zur Geschichte Osteuropas 6).

Dziadzio, Andrzej. "Das ABGB in Polen”. In Österreichs Allgemeines Bürgerliches Gesetzbuch (ABGB). Eine europäische Privatrechtskodifikation III: Das ABGB außerhalb Österreichs, ed. Elisabeth Berger, 205-226. Berlin: Duncker und Hublot, 2010.

Górnicki, Leonard. Prawo cywilne w pracach Komisji Kodyfikacyjnej Rzeczypospolitej Polskiej w latach 1919-1939, Wrocław: Kolonia Limited, 2000.

Grodziski, Stanisław. Historia ustroju społeczno-politycznego Galicji 1772-1848. Wrocław: Ossolineum, 1971.

Grodziski, Stanisław. „Komisja Kodyfikacyjna Rzeczypospolitej Polskiej”, Czasopismo Prawno-Historyczne 33, 1 (1981): 47-81.

Grodziski, Stanisław. "Justizreformen in Galizien in der Regierungszeit Maria Theresias und Joseph II”. In Österreich - Polen. 1000 Jahre Beziehungen, eds. Józef Buszko, Walter Leitsch, 123-132. Kraków: Wydawnictwo Uniwersytetu Jagiellońskiego, 1996.

Harmat, Ulrike. Ehe auf Widerruf? Der Konflikt um das Eherecht in Österreich 1918-1938, Frankfurt am Main: Klostermann, 1999 (= Studien zur Europäischen Rechtsgeschichte 121).

Lenhoff Arthur. “§§1255-1258”. In Kommentar zum Allgemeinen Bürgerlichen Gesetzbuch, III, ed. Heinrich Klang, 830-2. Wien: Österreichische Staatsdruckerei, 1932.

Lentze, Hans. Die Universitätsreform des Ministers Graf Leo Thun-Hohenstein. Wien: Hermann Böhlaus Nfg/Österr. Akademie Der Wissenschaften, 1962 (= Sitzungsberichte der philosophisch-historischen Klasse der Österreichischen Akademie der Wissenschaften 239/2).

Longchamps de Berier, Roman. Ernest Till jako cywilista [Ernest Till as an expert on civil law]. Lwów: nakł. autora, 1926. 
Malec, Dorota. „Das ABGB in den Arbeiten der polnischen Kodifizierungskommission 19191939. Ein positives oder negatives Modell”. In Die österreichische Kodifikation im internationalen Kontext 200 Jahre ABGB (1811-2011), eds. Barbara Dölemeyer, Heinz Mohnhaupt, 235-253. Frankfurt a M.: Vittorio Klostermann, 2012.

Mączyński, Andrzej (ed.). Fryderyk Zoll, 1865-1948. Prawnik - uczony - kodyfikator. Kraków: Polska Akademia Umiejętności [Polish Academy of Skills], 1994.

Neschwara, Christian. Karl Anton Martini und sein Entwurf zum Bürgerlichen Gesetzbuch. Accessed February 20, 2020, https://homepage.univie.ac.at/Christian.Neschwara/wp-content/ uploads/Martini-und-das-ABGB-formatiert.pdf.

Neschwara, Christian. "Westgalizisches Gesetzbuch". In Handwörterbuch zur deutschen Rechtsgeschichte, eds. Adalbert Erler, Ekkehard Kaufmann, 1308-1313. Berlin: E. Schmidt, 1998.

Neschwara, Christian. "Das ABGB in Ungarn”. In Österreichs Allgemeines Bürgerliches Gesetzbuch (ABGB). Eine europäische Privatrechtskodifikation III: Das ABGB außerhalb Österreichs, ed. Elisabeth Berger, 33-133. Berlin: Duncker \& Humblot, 2010.

Ofner, Julius. Der Ur-Entwurf und die Berathungs-Protokolle des Oesterreichischen Allgemeinen Bürgerlichen Gesetzbuches, II, Wien: Alfred Hölder, 1889.

Ogris, Werner. "Die Universitätsreform des Ministers Leo Graf Thun-Hohenstein". In Ogris Werner Elemente europäischer Rechtskultur, ed. Thomas Olechowski, 333-4. Wien-Köln-Weimar: Böhlau Verlag, 2003.

Olechowski, Thomas. „Jurisprudenz oder Rechtswissenschaft? - Zur Entwicklung des wissenschaftlichen Leitbildes der juristischen Fakultät der Universität Wien seit 1852". In Reflexive Innensichten aus der Universität. Disziplinengeschichten zwischen Wissenschaft, Gesellschaft und Politik, eds. Karl A. Fröschl [et al.], 401-416. Göttingen: V \& R unipress: Vienna University Press, 2015 (=650 Jahre Universität Wien - Aufbruch ins neue Jahrhundert 4).

Pfaff, Leopold. „Zur Entstehungsgeschichte des westgalizischen Gesetzbuchs”, Juristische Blätter 19 (1890): 399-401, 411-5, 423-5, 435-7.

Redzik, Adam. Prawo prywatne na uniwersytecie Jana Kazimierza we Lwowie. Warszawa: C.H. Beck, 2009.

Salák, Pavel. "Tschechoslowakei: Rekodifizierung des Bürgerlichen Rechts". In "Nichtgeborene Kinder des Liberalismus"? Zivilgesetzgebung im Mitteleuropa der Zwischenkriegszeit, eds. Martin Löhnig and Stephan Wagner, 91-148. Tübingen: Mohr Siebeck, 2018.

Schey, Josef (ed.). Das Allgemeine Bürgerliche Gesetzbuch, Wien: Manz, 1936.

Schneider, Karin. "Zwischen «Monarchischer Union von Ständestaaten» und Gesamtstaat. Die Habsburgermonarchie im 18. und 19. Jahrhundert”. In Rechtshistorische Aspekte des österreichischen Föderalismus, ed. Martin Schennach, 31-49. Wien: Verlag Österreich, 2015.

Slapnicka, Helmut. Österreichs Recht ausserhalb Österreichs. Der Untergang des österreichischen Rechtsraums. Wien: Verlag für Geschichte und Politik, 1973 (= Schriftenreihe des österreichischen Ost- und Südosteuropa-Instituts 4).

Sójka-Zielińska, Katarzyna. Wielkie kodyfikacje cywilne. Historia i współczesność. Warszawa: Liber, 2009.

Staudigl-Ciechowicz, Kamila. "Zwischen Wien und Czernowitz - österreichische Universitäten um 1918”, Beiträge zur Rechtsgeschichte Österreichs 4 (2014): 223-38.

Staudigl-Ciechowicz, Kamila. "Österreich: Das österreichische Zivilrecht und die österreichische Zivilrechtswissenschaft in der Zwischenkriegszeit". In "Nichtgeborene Kinder des Liberalismus"? Zivilgesetzgebung im Mitteleuropa der Zwischenkriegszeit, eds. Martin Löhnig, Stephan Wagner, 39-69. Tübingen: Mohr Siebeck, 2018.

Till, Ernest. Prawo prywatne austryackie [Austrian civil law], I-VI. Lwów: Księgarnia Seyfartha i Czajkowskiego [et al.], 1884-1904. 
Till, Ernest. "Przyczynek do materiałów kodeksu cyw. austriackiego" [Contribution to the materials of the Austrian Civil Code]. Przeglad Prawa i Administracji 27 (1902): 178-98, 268-78, 351-8; 28 (1903): 200-8; 29 (1904): 221-33, 279-89, 358-64, 445-54, 524-34.

Till, Ernest. “Czy rewizja Kodeksu cywilnego konieczna?" [Is a revision of the Civil Code necessary?]. Przeglad Prawa i Administracji 31 (1906): 601-14.

Till, Ernest. "Revision oder Ergänzung des allgemeinen Bürgerlichen Gesetzbuches?" [Revision or amendment of the Austrian Civil Code?]. Allgemeine österreichische Gerichts-Zeitung 58 (1908): 41-5.

Till, Ernest. Obrady trybunatu szlacheckiego w Tarnowie o t.zw. Galicyjskim Kodeksie Cywilnym $z$ roku 1797 [Debates of the forum nobilium in Tarnów on the so-called Galician Civil Code of 1797.]. Lwów 1909 (Odbitka z Przegladu Prawa i Administracji).

Unger, Joseph. System des österreichischen allgemeinen Privatrechts I, Leipzig: Breitkopf und Härtel, 1856.

Welser, Rudolf and Kletečka, Andreas. Grundriss des bürgerlichen Rechts I. 15. Auflage. Wien: MANZ, 2018.

Zeiller, Franz von. Commentar über das allgemeine Bürgerliche Gesetzbuch für die gesammten Deutschen Erbländer der Oesterreichischen Monarchie. Wien-Triest: Geistingers Verlagsbuchhandlung, 1811.

Zobkow, Michael. "Das österreichische Advitalitätsrecht". Zeitschrift für das Privat- und Öffentliche Recht der Gegenwart 32 (1904): 747-59; 33 (1905): 271-80, 511-36. 